\title{
KEGUNAAN REHABILITASI DAN TERAPI DALAM CEDERA OLAHRAGA
}

Oleh: Ali Satia Graha Dosen Jurusan Pendidikan Kesehatan dan Rekreasi FIK UNY

\begin{abstract}
Abstrak
Cedera olahraga yang terjadi sangat bermacam-macam pada lokasi tubuh manusia, mulai dari tingkat paling ringan vaitu berupa nyeri, keluhan lelah, dan lesu berkepanjangan. Yang paling berat berupa hilangnya fungsi gerak karena cedera otot atau patah tulang. Jika kondisi itu tidak ditangani dengan tepat, tentu dapat mengganggu aktivitas kehiduoan dan kesehatan secara umum.

Terapi sangat membantu sebagai upaya penyembuhan cedera olahraga dan bukan pengobatan cedera olahraga, karena dalam pelaksanaannya terapi dalam rehabilitasi tidak menggunakan obat-obatan, namun melalui latihan dan pemanfaatan alam sebagai sarana penyembuhan dalam penanganan cedera olahraga.

Kegunaan rehabilitasi dan terapi dalam cedera olahraga sangat bermanfaat bagi individu atlet yang membutuhkan layanan khusus. Ditinjau dari - segi medis hal ini mempunyai fungsi sebagai pencegahan, peningkatan, penyembuhann, dan pemuliahan. Seorang olahragawan yang mengalami cedera setelah melakukan aktivitas dajàt kembali melakukan aktivitas olahraga tanpa mengalami rasa nyeri maupun lelah setelah mendapatkan layanan rehabilitasi dan terapi.
\end{abstract}

Kata-kata kunci: cedera olahraga, terapi, rehabilitasi. 
Olahraga dalam peradaban modern sekarang ini merupakan aktivitas fisik yang memiliki banyak manfaat terhadap kehidupan manusia, antara lain untuk kesehatan, pendidikan, rekreasi, dan prestasi. Meskipun demikian tidak sedikit orang yang melakukan aktivitas olahraga mengalami cedera akibat kecelakaan. Menurut Azrul Ananda (2002: 20) dikutip oleh Y. Sukarmin (2004: 1) dikatakan bahwa sekitar empat juta anak di Amerika setiap tahun terpaksa dibawa kerumah sakit akibat cedera saat berolahraga. Sekitar $95 \%$ cedera yang dialami oleh anakanak tersebut berupa luka iris, lecet, memar, cedera otot, dan beberapa kondisi yang serupa. Kejadian seperti inilah kiranya yang menjadi penyebab ketidak sukaan beberapa orang tua pada oĺahraga.

Cedera Olahraga dapat mengenai semua bagian tubuh, terutama daerah yang memiliki fungsi gerak atau menjadi tumpuan selama beraktivitas, yang ditandai dengan adanya gejala nyeri, bengkak, memar, lecet, teriris dan patah pada tulang.

Giam dan Teh (1993: 137-138) yang dikutip oleh Y. Sukarmin (2004: 7) membedakan cedera olahraga akibat kecelakaan menjadi tiga macam yaitu: (1) cedera ringan adalah cedera yang tidak sampai mengganggu performance atlet, seperti: lecet dan memar, (2) cedera sedang adalah cedera yang menimbulkan gangguan pada performance atlet, seperti: strain dan sprain, dan (3) cedera berat adalah cedera yang memerlukan istirahat total dan intensif, bahkan harus operasi, seperti: fractur tulang dan ligamen atau otot putus total atau hampir total. Dari hasil beberapa penelitian yang berkembang di Amerika menyatakan bahwa prevalensi cedera olahraga adalah 1 banding 4 atau sekitar $25 \%$ yang terjadi sekarang ini. Di Indonesia sendiri belum ada data resmi (Imran, 2004: 4).

Penyebab cedera dalam aktivitas berolahraga disebabkan oleh faktor internal seperti cara latihan yang kurang tepat, kurangnya peregangan terhadap otot tertentu sebagai penggerak utama, kekuatan yang begitu rendah, pemanasan dan pendinginan yang tidak tepat cenderung akan berakibat kepada keluhan rasa nyeri yang akan terasa 24 sampai 28 jam setelah latihan. Sedangkan yang bersifat eksternal dapat disebabkan karena pemasangan alat yang tidak tepat, kondisi alat yang tidak layak pakai, perlengkapan latihan yang tidak sesuai, lingkungan latihan yang tidak aman untuk kegiatan maupun dari karakteristik cabang olahraga itu sendiri (Sayuti Syahara, 2004: 64).

Cedera olahraga paling ringan berupa nyeri atau keluhan lelah dan lesu berkepanjangan. Yang paling parah berupa hilangnya fungsi gerak karena cedera otot atau patah tulang. Jika kondisi itu tidak ditangani dengan tepat, tentu dapat mengganggu aktivitas kehiduoan dan kesehatan secara umum. 
Dalam pelaksanaan rehabilitasi untuk cedera olahraga telah tersedia suatu layanan berupa terapi. Dalam makalah ini yang akan dibahas hanya lokasi cedera olahraga, rehabilitasi dan terapi.

\section{LOKASI CEDERA OLAHRAGA}

Menurur Imran (2004: 5) bagian tubuh yang rawan cedera saat berolahraga mulai dari punggung hingga mata kaki yaitu: (1) salah ligamen pada punggung dengan gejala yang timbul adalah sakit, bengkak dan memar pada bagian punggung bawah karena peregangan otot atau tendon. Sering dipicu oleh kurangnya pemanasan pada bagian dada, punggung dan perut, (2) salah ligamen pada otot paha atas dengan gejala yang timbul adalah sakit, bengkak dan memar pada bagian atas dan samping. Hal ini disebabkan oleh peregangan otot atau tendon. Sering terjadi pada pergerakan yang cepat, misalnya pada olahraga basket, lari dan seluncur es, (3) salah ligamen pada lutut dengan gejala yang timbul adalah sakit, bengkak, dan sedikit memar pada daerah lutut karena peregangan otot atau tendon. Olahraga yang relatif berisiko adalah lari, bersepeda, dan renang, (4) pembengkakan pada kaki dengan gejala yang timbul adalah sakit, bengkak dan memar yang terlihat jelas, disebabkan oleh lari basket dan olahraga lain yang menggunakan otot kaki, (5) pembengkakan tumit dengan gejala sakit disekitar tumit biasanya karena tendon tegang. Penyebabnya diakibatkan karena pemanasan yang kurang dan picmakaian sepatu yang tidak tepat, (6) otot bahu tertarik dengan gejala yang timbul adalah saki, bengkak, memar pada daerah bahu karena peregangan otot pada tendon. Cedera ini terjadi pada basket, tennis lapangan, tennis meja, badminton, golf, dan berenang, (7) sakit pada siku dengan - gejala yang timbul adalah sakit pada daerah siku apabila siku digerakan. Dipicu oleh ketegangan pada tendon dan kontraksi otot tidak normal. Cedera ini tejadi pada olahraga tennis lapangan, (8) shinsplints dengan gejala yang timbul adalah sakit pada kaki bagian depan atau samping, yang disebabkan nyeri tulang, tendon atau otot pada betis dimana sering

terjadi pada olahraga lari, (9) ligamen lutut yang tertarik dengan gejala yang timbul adalah sakit bengkak, dan kemungkingan memar di sekitar ligamenligamen yang terdapat pada sisi belakang lutut dimana sering di picu oleh pemanasan yang kurang benar, dan (10) cedera mata kaki dengan gejala yang timbul adalah sakit, bengkak dan sedikit memar pada sekitar mata kaki, penyebabnya karena timbul peregangan dan ketegangan pada ligamen. 


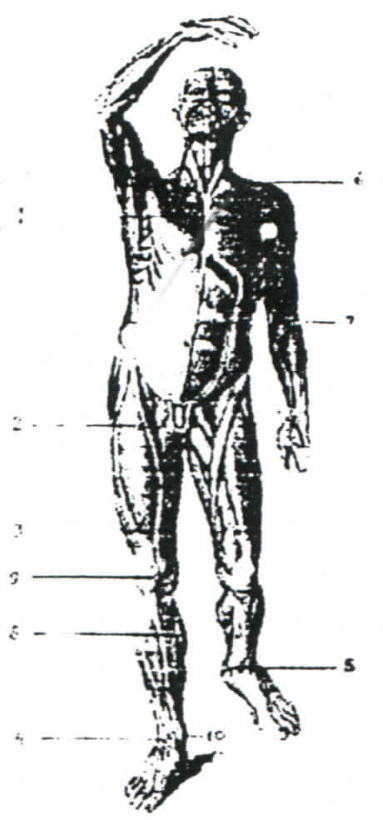

Gambar 1. Bagian tubuh yang rawan cedera saat berolahraga mulai dari punggung hingga mata kaki

Sumber: Imran, (Mengolah Raga Tanpa Cedera, Senior No. 258, 2004: 5)

Bagian tubuh yang rawan cedera saat berolahraga mulai dari punggung hingga mata kaki disajikan dalam gambar 1 .

Penanganan cedera olahraga yang tepat menurut Edwar R. Laskowski, MD, Wakil Direktur Mayo Clinic's Sport Medicine Center di Ochester, Minnesota, AS, dikutip (Imran, 2004: 5) mengungkapkan bahwa langkah yang harus diambil jika terjadi cedera adalah menghentikan olahraga. Selanjutnya lakukan observasi sendiri, apakah ada jaringan yang cedera. Hal itu dapat dikenali dari munculnya bengkak, kemerahan, dan rasa nyeri. Segera hubungi dokter bila terjadi parah. Kondisi ini perlu mendapatkan penanganan rehahilitasi medik yang terpadu agar jaringan yang cedera bisa normal kembali.

Dalam cedera olahraga yang perlu diperhatikan adalah mengenali perbedaan cederanya, baik ringan, sedang maupun berat. Hal itu dapat dikenali dari munculnya bengkak, kemerahan, rasa nyeri dan kondisi lainnya pada cedera tersebut untuk memudahkan pelayanan rehabilitasi yang akan diberikan.

\section{REHABILITASI}

Rehabilitasi merupakan suatu rangkaian kegiatan yang bertujuan untuk melakukan aksi pencegahan, peningkatan, penyembuhan memberikan serta memulihkan kemampuan kepada individu yang membutuhkan layanan khusus. Kaitan dengan cedera olahraga tersebut, tindakan rehabilitasi sangat diperlukan, hal tersebut didasarkan atas masalah yang dialami oleh tiap-tiap individu, layanan diberikan secara terpadu dan berkesinambungan (Tarmansyah, 2003: 6)

Menurut Susan J. G dialihbahasakan oleh Anton C, W (2001: 325-326), penanganan rehabilitasi dalam cedera olahraga ada delapan prinsip dasar kedokteran olahraga yang ditinjau dari sudut pandang fisik, yaitu:

1. kendali inflamasi

2. kontrol nyeri

3. pemulihan jangkauan gerak sendi dan ekstensibilitas jaringan lunak 
4. pemulihan kekuatan otot

5. pemulihan daya tahan otot termasuk mengurangi beban

6. pelatihan kembali biomekanika

7. pemeliharaan kebugaran kardiovaskuler

8. pengembangan program

Delapan prinsip dasar kedokteran olahraga dari sudut pandang fisik disajikan dalam bagan 2 .

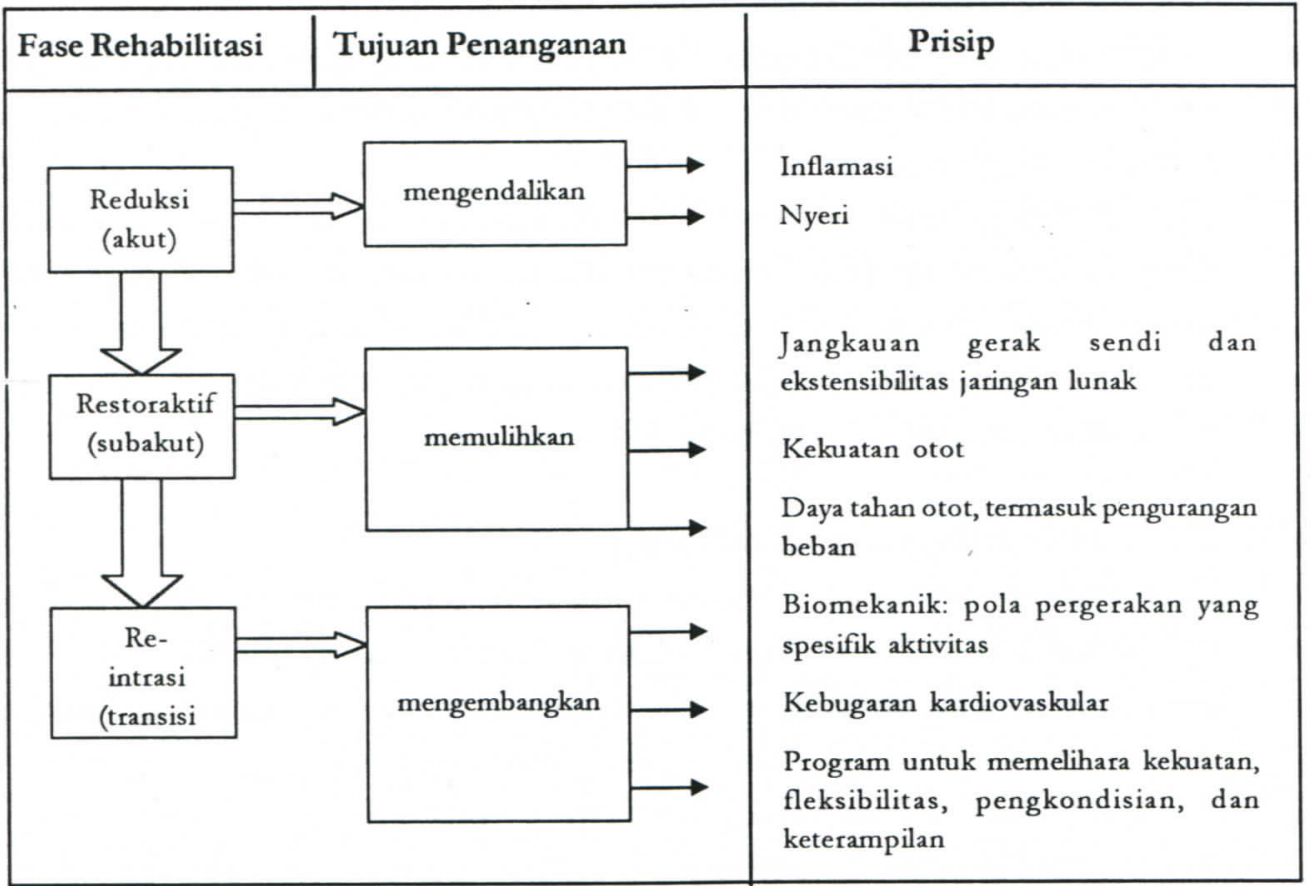

Fase-fase rehabilitasi yang berhubungan dengan prinsip-prinsip cedera olahraga menurut Susan J. G dialihbahasakan oleh Anton C, W (200: 327-328) meliputi:

\section{Fase Reduksi (Akut)}

Fase ini meliputi inflamasi dan kontrol nyeri, memusatkan diri pada pengendalian tanda-tanda dan gejala-gejala akut suatu cedera. Pada cedera akut, gejala-gejalanya meliputi nyeri dan inflamasi sebagai akibat cedera jaringan setempat. Cedera ini dapat melibatkan trauma makro dan/atau mikro.Prinsip (protection, rest, ice, compression and elevation) PRINCE merupakan suatu sarana intervensi efektif yang dapat diterapkan. Tindakan-tindakan ini harus dilakukan sesegera mungkin setelah cedera. Pada cedera kronik, tanda 
dan gejala tidak begitu jelas, namun demikian proteksi, istirahat dan pendinginan dengan es tetap merupakan tindakan yang penting.

\section{Fase Pemulihan (Sub-akut)}

Fase ini meliputi pemulihan jangkauan gerak sendi dan ekstensibilitas jaringan lunak serta pemulihan kekuatan dan daya tahan otot, termasuk pengurangan beban. Cedera ini sekarang bersifat sub-akut, telah diobati saat akut pada fase reduksi. Terapi dirancang untuk mempersiapkan jaringan untuk kembali pada fungsi yang terintegrasi dalam tugas yang spesifik. Fleksibiltas (Range Of Movement) ROM dipulihkan terlebih dahulu, diikuti dengan kekuatan, dan kemudian daya tahan.

Fase ini mungkin memakan waktu paling lama dan tenaga yang besar dalam terapi. Lanjutan ke fase berikutnya dilakukan setelah berhasil memulihkan fleksibilitas, kekuatan dan daya tahan. Hal itu penting untuk memelihara kebugaran kardiovaskular dengan cara yang masih memungkinkan terjadinya pemulihan jaringan yang mengalami cedera.

\section{Fase Re-integrasi (Transisi)}

Fase ini berisi tingkatan-tingkatan pelatihan fungsi kembali. Dimulai dengan latihan yang berkaitan dengan olahraga berkecepatan rendah. Sekali tugas dilakukan dengan tepat, pengulangan ditingkatkan dan kemudian kecepatan kinerja tersebut ditingkatkan. Latihan kemudian dikelompokkan ke dalam sesi-sesi. Sekali sesi dikuasai pada suatu bentuk yang sama dengan tiap-tiap latihan, atlet tersebut dikembangkan dengan manuver atau aktivitas olahraga yang spesifik.

Apabila atlet tersebut telah menguasai keterampilan yang diperlukan untuk melakukan olahraga dalam bentuk yang aman dan efisien, praktik aktivitas dengan teratur dapat dimulai. Pada saat yang sama, kebugaran kardiovaskular yang telah diraih dipertahankan. Kedua aktivitas ini bergabung saat atlet tersebut mulai melakukan olahraga untuk periode waktu yang lebih lama.

Sejalan dengan Susan J.G, usaha penangan cedera olahraga tidak terlepas dari fase-fase rehabilitasi dan prinsif penanganan cedera olahraga yang meliputi: (1) fase reduksi (akut) yang bertujuan untuk mengendalikan pada inflamasi dan nyeri, (2) fase restoratif (subakut) yang bertujuan untuk memulihkan pada jangkauan gerak sendi, ekstensibilitas jaringan lunak, kekuatan otot, dan daya tahan otot, (3) fase re-integrasi yang bertujuan untuk mengembangkan pada 
biomekanika, kebugaran kardivaskular, dan program untuk memelihara kekuatan, fleksibilitas, pengkondisian dan keterampilan. Ketiga fase rehabilitasi dan prtinsif penanganan cedera olahraga yang telah diketahui, akan memudahkan dalam pemberian macam dan teknik terapi untuk penderita cedera olahraga.

\section{TERAPI}

Menurut Tarmansyah (2003: 7, 26) terapi mempunyai makna sebagai upaya penyembuhan dan bukan pengobatan, karena dalam pelaksanaannya terapi dalam rehabilitasi tidak menggunakan obat-obatan, namun melalui latihan dan pemanfaatan alam sebagai sarana penyembuhan. Dari makna di atas dapat didefinisikan bahwa terapi adalah sebagai suatu usaha penyembuhan yang dilakukan secara terprogram dan sistematis melalui suatu proses identifikasi, analisis, diagnosis, penyusunan layanan dan evaluasi serta tindak lanjut sebagai rekomendasi layanan.

Kegunaan terapi dalam cedez̃a olahraga menurut terapi kedokteran olahraga, ada tujuh macam, (Susan J. G yang dialihbahasakan oleh Anton C, W, 2001 : 334-335): (1) pelepasan miofasial adalah pijatan yang dalam, pada suatu daerah dengan tujuan untuk membebaskan lapisan jaringan dari pembatasan gerak, dengan mengurangi rasa nyeri dan meningkatkan penyatuan fungsi jaringan., (2) lepas beban adalah suatu metode meringankan sebagian dari berat badan pasien (dengan bantuan katrol atau dengan air) untuk menguranoi impaksi pada suatu daerah tertentu selama latihan, dengan membuat pasien tersebut berlatih dalam parameter-parameter pembatasan tenggungan berat beban, (3) peregangan dilakukan baik dalam bentuk dinamik maupun statik antara lain; (a) "pasif yaitu hanya menggunakan gaya eksternal, aktif dibantu menggunakan kombinasi gaya eksternal dan internal, (b) aktif yaitu hanya menggunakan tenaga yang diberikan oleh orang itu sendiri, (c) fasilitasi neuromuskular pronoseptif (PNF) dimana antagonis otot diaktifkan, kemudian peregangan pasif terjadi, (4) penguatan adalah suatu program kontraksi otot yang meliputi; (a) konsentrik adalah suatu kontraksi pemendek, (b) eksentrik adalah suatu kontraksi pemanjang, (c) isometrik adalah mengaktifkan otot tanpa pergerakan, (d) isotonik adalah memindahkan beban yang sama dengan kontrkasi otot, (e) isokinetik adalah memindahkan berbagai beban dengan kontraksi otot pada kecepata yang sama, (5) proprioseptif adalah latihan yang meningkatkan perasaan posisi tanpa input visual untuk meningkatkan fungsi sendi, (6) terapi manual artikulasi adalah 
suatu teknik osilasi ritmik yang diterapkan pada suatu sendi yang mencoba mengembalikan mekanisme netral pada sendi itu antara lain; (a) tenaga otot yaitu pasien mengerahkan gaya dengan mengaktifkan otot yang digunakan oleh juru pulih untuk mempengaruhi struktur tulang tempat lekat otot tersebut, (b) kecepatan-tinggi/amplitudo rendah yaitu daya tolak cepat namun bertenaga yang diberikan secara eksternal oleh juru pulih yang digunakan dengan berhati-hati, terutama pada pasien tua dan renta, (7) terapi alternatif antara lain, (a) pilates adalah latihan yang meningkatkan gerakan ritmik melalui kekuatan berbasis proksimal, fleksibilitas, dan koordinási, (b) feldenkrais yaitu pemakaian gerakan untuk meningkatkan kewaspadaan kinestetik, mampu melakukan gerakan yang lebih baik dan lebih aman, (c) teknik alexander yaitu berpusat pada kewaspadaan kinetik, terutama pada kepala dan leher, untuk memperbaiki postur selama pergerakan, (d) terapi latihan air yạitu peniadaan beban melalui pembenaman dalam air, yang dapat membuat tingkat peniadaan beban lebih besar daripada terapi yang berbasis tanah, (e) pitometrics yaitu aktivitas dengan menggunakan kontraksi otot eksentrik yang cepat untuk memudahkan kontraksi konsentrik yang lebih bertenaga, ( $f$ ) pengerasan usaha yaitu terapi yang dirancang untuk mengembalikan pekerja pada lingkungan pekerjaannya dalam bentuk yang aman dan efisien, $(g)$ aktivitas rantai kinetik terbuka yaitu aspek distal dari anggota gerak yang dilatih tidak menanggung berat, (h) aktivitas rantai kinetik tertutup adalah aspek distal dari anggota gerak yang menanggung berat selama latihan, lebih berbasis fungsional daripada aktivitas rantai kinetik terbuka.

Mengerti akan kegunaan terapi, membantu sekali dalam proses sebelum dilakukannya penanganan pasien yang akan di terapi, seperti halnya pemilihan jenis terapi yang sesuai dengan keluhan yang dialami pasien tersebut. Pendapat Tarmansyah (2003: 31) jenis terapi dalam rehabilitasi yang dapat menangani gangguan pada individu meliput:

1. Masase adalah terapi yang diberikan melalui pijatan yang terdiri atas segmen masase, sport masase

2. Hidro terapi adalah penyembuhan dengan tenaga air, baik air dingin maupun air panas sebagai kompres, bisa juga melakukan kegiatan renang, atau air yang berputar

3. Termo terapi adalah penggunaan air panas, kompres panas, atau air dingin guna memberikan stimulasi pada kondisi pembengkakan; dan mengurangi rasa nyeri pada otot 
4. Elektro terapi adalah terapi memanfaatkan tenaga terapi listrik yaitu: fibrasi, infra red, stimulasi elektro.

Adapun pemilihan macam terapi dan teknik terapi sangat penting diperhatikan dalam penanganan cedera olahraga baik cedera ringan, sedang maupun berat, serta mengingat indikasi dan kontra indiksi yang akan terjadi pada penangan cedera tersebut.

\section{KESIMPULAN}

1. Sasaran untuk penangan cedera olahraga tidak terlepas dari fase-fase rehabilitasi dan prinsif penanganan yang meliputi: (1) fase reduksi (akut) yang bertujuan untuk mengendalikan pada inflamasi dan nyeri, (2) fase restoratif (subakut) yang bertujuan untuk memulihkan pada jangkauan gerak sendi, ekstensibilitas jaringan lunak, kekuatan otot, dan daya tahan otot, (3) fase reintegrasi yang bertujuan untuk mengembangkan pada biomekanika, kebugaran kardivaskular, dan program untuk memelihara kekuatan, fleksibilitas, pengkondisian, dan keterampilan.

2. Terapi sangat membantu dalam sebagai upaya penyembuhan cedera olahraga dan bukan pengobatan cedera olahraga, karena dalam pelaksanaannya terapi dalam rehabilitasi tidak menggunakan obat-obatan, namun melalui latihan dan pemanfaatan alam sebagai sarana penyembuhan dalam penangan cedera olahraga.

3. Kegunaan rehabilitasi dan terapi dalam cedera olahraga sangat bermanfaat bagi individu atlet yang membutuhkan layanan khusus. Ditinjau dari segi medis hal itu mempunyai fungsi sebagai pencegahan, peningkatan, penyembuhann, dan pemuliahan. Seorang olahragawan yang mengalami cedera setelah melakukan aktivitas dapat kembali melakukan aktivitas olahraga tanpa mengalami rasa nyeri maupun lelah setelah mendapatkan layanan rehabilitasi dan terapi. 


\section{Referensi}

Imron (2004), Mengolab Raga Tanpa Cedera, Senior No. 258, 25 Juni-1 Juli 2004, halaman 3, Jakarta, PT. Raketindo Prima Media Mandiri.

Sayuti Syahara (2004). Pencegaban Cedera dalam Pendidikan Jasmani dan Olabraga. Jurnal Nasional Pendidikan Jasmani dan Ilmu Keolahragaan, Volume 3. Proyek Pengembangan dan Keserasian Olahraga. Direktorat Jendral Olahraga. Departemen Pendidikan Nasional.

Susan. J. G (2001), Dasar-dasar Terapi dan Rehabilitasi Fisik, Jakarta, Hipokrates.

Tarmansyah (2003), Rebabilitasi dan Terapi Untuk Individu Yang Membutubkan Layanan Khusus, Depdikbud, DIKTI, Direktorat Pembinaan Penelitian dan Pengabdian Pada Masyarakat. 